\title{
Two Alternatively Spliced Forms of the cGMP-Gated Channel $\alpha$-Subunit from Cone Photoreceptor Are Expressed in the Chick Pineal Organ
}

\author{
Wolfgang Bönigk, ${ }^{1}$ Frank Müller, ${ }^{1}$ Ralf Middendorff, ${ }^{2}$ Ingo Weyand, ${ }^{1}$ and U. Benjamin Kaupp ${ }^{1}$ \\ 1/nstitut für Biologische Informationsverarbeitung, Forschungszentrum Jülich, D-52425 Jülich, Germany, and \\ 2Anatomisches Institut, Universitätskrankenhaus Eppendorf, D-20246 Hamburg, Germany
}

Light sensitivity of the pineal has been retained in most vertebrates, except mammals. Retinal photoreceptors and pinealocytes share common components of light-dependent signaling pathways. In particular, an ion channel gated by cGMP has been electrophysiologically identified in chick pinealocytes; however, the physiological function of a light-sensitive enzyme cascade is not known, and primary structures of only a few pineal components have been determined. By PCR analysis and cloning of the respective cDNA, we show that the chick pineal expresses the $\alpha$-subunit of the cyclic nucleotide-gated (CNG) channel of rod photoreceptors and two short forms of the cone CNG channel. Analysis of the chick cone CNG channel gene reveals that these forms are produced by alternative splicing, which removes either one or two exons from the transcript. The shorter splice variant is functional when heterologously expressed, and it is approximately twofold more sensitive to activation by cGMP than the cone CNG channel. The chick cone CNG channel and the pineal splice form are both modulated by $\mathrm{Ca}^{2+} /$ calmodulin (CaM). The CaM sensitivity might be mediated by a putative CaM-binding site in an $\mathrm{N}$-terminal segment encoded by exon 4. This exon is missing in the gene for the rod CNG channel $\alpha$-subunit. Pineal CNG channels are candidates for receptor-mediated $\mathrm{Ca}^{2+}$ entry into pinealocytes and may be an important element of signaling pathways that control the light response and secretion of the pineal hormone melatonin.

Key words: ion channels; cyclic nucleotides; calmodulin; calcium; signal transduction; pineal gland
The pineal regulates various physiological functions by nocturnal secretion of the hormone melatonin. The control of melatonin release differs between mammals and birds. Chick pinealocytes exhibit an intrinsic circadian rhythm of melatonin secretion (Deguchi, 1979; Takahashi et al., 1989), whereas in mammals, a circadian clock in the suprachiasmatic nucleus of the hypothalamus controls pineal activity (for review, see Takahashi, 1995).

Two neural pathways, one involving noradrenaline (NE) and the other involving vasoactive intestine peptide (VIP), regulate the synthesis of melatonin (for review, see Takahashi et al., 1989). Modulation of melatonin secretion by NE differs among vertebrates. In the chick, NE inhibits the nocturnal elevation of melatonin levels (Pratt and Takahashi, 1989), whereas in the rat pineal it stimulates melatonin synthesis (Klein, 1986). Both inhibitory and stimulatory effects of NE are mediated by a cAMP-signaling pathway. In the chick, NE inhibits adenylate cyclase via $\alpha_{2}$ adrenergic receptors (Voisin and Collin, 1986), whereas in the rat it stimulates cAMP synthesis via $\alpha_{1}$ - and $\beta$-adrenergic receptors. Thus, although cAMP stimulates melatonin synthesis in both avian and mammalian pinealocytes, the mechanisms that control cAMP levels differ. In both chick and rat, VIP stimulates the

\footnotetext{
Received July 10, 1996; revised Sept. 5, 1996; accepted Sept. 12, 1996.

This work was supported by a grant from the Deutsche Forschungsgemeinschaft (I.W.). We thank Drs. H.-W. Korf and E. Maronde (Frankfurt) for the initial supply of chick and bovine pineals, and Drs. H.-W. Korf and J. Olcese (Hamburg) for comments on an earlier version of this manuscript. We are particularly grateful to Dr. E. Eismann for many helpful suggestions on this manuscript. We express our gratitude to Dr. R. S. Molday (Vancouver) for a gift of antibodies 63-4 and PPcCC1. We thank M. Bruns for technical assistance and A. Eckert for preparing this manuscript.

Correspondence should be addressed to Dr. U. Benjamin Kaupp, IBI-1, Forschungszentrum Jülich, Postfach 1913, D52425 Jülich, Germany.

Copyright (C) 1996 Society for Neuroscience $\quad 0270-6474 / 96 / 167458-11 \$ 05.00 / 0$
}

synthesis of melatonin, and it is believed that this effect is also mediated by a cAMP-signaling pathway (Yuwiler, 1983; Kaku et al., 1985; Pratt and Takahashi, 1989).

In addition, NE and VIP increase the concentrations of cGMP and $\mathrm{Ca}^{2+}$ (Sugden et al., 1987; D'Souza and Dryer, 1994; Schaad et al., 1995; Schomerus et al., 1995). Although the physiological functions of both messenger molecules and their cellular targets in the pineal are poorly understood, some evidence supports a modulatory role of $\mathrm{Ca}^{2+}$ for melatonin synthesis (Takahashi et al., 1989); however, the mechanisms that give rise to changes in intracellular $\mathrm{Ca}^{2+}$ concentration $\left(\left[\mathrm{Ca}^{2+}\right]_{\mathrm{i}}\right.$ ) have not been identified unequivocally (D'Souza and Dryer, 1994; Saez et al., 1994; Chik et al., 1995; Schaad et al., 1995).

Recently, cyclic nucleotide-gated (CNG) channel activity has been recorded from chick pinealocytes (Dryer and Henderson, 1991, 1993). Because of their substantial $\mathrm{Ca}^{2+}$ permeability (for review, see Kaupp, 1995), CNG channels may be utilized by G-protein-coupled receptor pathways to control $\left[\mathrm{Ca}^{2+}\right]_{i}$ in pinealocytes through changes in the concentration of cAMP and cGMP. CNG channels comprise two homologous polypeptides, designated $\alpha$ - and $\beta$-subunits (Chen et al., 1993; Bradley et al., 1994; Liman and Buck, 1994; Körschen et al., 1995). Three different genes encoding $\alpha$-subunits have been identified in vertebrates. They were first discovered in rod and cone photoreceptors and olfactory sensory neurons (OSNs), but they are also expressed in other cellular systems (for reviews, see Eismann et al., 1993; Finn et al., 1996). CNG channels vary considerably in their ability to conduct $\mathrm{Ca}^{2+}$ (Perry and McNaughton, 1991; Frings et al., 1995; Picones and Korenbrot, 1995). In some cellular systems, the principal if not exclusive function of $\mathrm{CNG}$ channels even might be 
to control $\left[\mathrm{Ca}^{2+}\right]_{\mathrm{i}}$ rather than to change the membrane voltage by passing $\mathrm{Na}^{+}$or $\mathrm{K}^{+}$ions.

To study the function of $\mathrm{CNG}$ channels in pinealocytes, we have identified CNG channel isoforms by cloning, functional expression, and immunohistochemical localization. Here, we report that chick pineals express the $\alpha$-subunit of the rod CNG channel and two splice variants of the cone CNG channel $\alpha$-subunit. Analysis of the structure of the cone $\alpha$-subunit gene revealed that either one or two exons are missing in the splice variants. These exons encode two segments in the cytoplasmic N-terminal region. Expression of one splice variant in Xenopus oocytes and a mammalian cell line gave rise to cGMP-activated currents. The splice variant is roughly twofold more sensitive to cGMP than the cone CNG channel itself. The activity of the cone CNG channel and of the splice variant is modulated by $\mathrm{Ca}^{2+} / \mathrm{CaM}$. Modulation is probably mediated by an $\mathrm{N}$-terminal domain that shares a high sequence similarity with a CaM-binding region in the $\alpha$-subunit of the olfactory CNG channel (Liu et al., 1994). CNG channels in the pineal may subserve two distinct functions: generation of the light response and regulation of $\left[\mathrm{Ca}^{2+}\right]_{\mathrm{i}}$ by efferent neural pathways.

\section{MATERIALS AND METHODS}

Preparation of RNA and synthesis of $c D N A$. Poly $(\mathrm{A})^{+}$RNA was isolated with a FastTrack Kit (Invitrogen, San Diego, CA) from 20 pineals of 1and 12 -d-old chicks, 10 chick retinae, $\approx 1 \mathrm{gm}$ of chick testis tissue, and $\approx 0.1 \mathrm{gm}$ of bovine pineal tissue, respectively. First-strand cDNA was synthesized with M-MLV reverse transcriptase (BRL, Bethesda, MD) using oligo-d $\mathrm{dT}_{17}$ as primer. Primers were removed by ultrafiltration with a Centricon 100 spin column (Amicon, Beverly, MA).

Amplification of PCR fragments and construction of complete cDNA clones. The presence of CNG channel transcripts in the pineal, the retina, and the testis was probed by amplification of PCR fragments with primers specific for the CNG channels of chick rod or cone photoreceptors and OSNs. First-strand cDNA transcribed from the respective poly $(\mathrm{A})^{+}$RNA was used as template. The coding region of the $\alpha$-subunit of the chick cone photoreceptor CNG channel (clone pCCG8B of Bönigk et al., 1993) was amplified using primer pair CC1 (TGGAGGCTGTCAACTTCG; positions -37 to 21 ) and CC2 (TCCTTCGTTACCTTTCG; inverse complement of positions 1405 to 1422), and primer pair CC3 (ATGATTTCCAACATGAA; positions 1330 to 1346) and CC4 (GATGGACCAAATCTCCC; inverse complement of positions 2392 to 2418). Primer pair CC5 (TAGAGCGTATCCGAGGG; positions 299 to 315) and CC6 (CAAGGAAGCCTGTCCTG; inverse complement of positions 792 to 808 ) were used to amplify a smaller fragment from the $5^{\prime}$ region of ccCNGC $\alpha$ (see Fig. 2). PCR fragments of the chick rod photoreceptor CNG channel (clone pCCG6 of Bönigk et al., 1993) were amplified using primer pair CR1 (AAGAAGCAGCAGATTAC; positions -43 to -27 ) and CR2 (GCTACTCGGAGCAGTCG; inverse complement of positions 676 to 692), and primer pair CR3 (GTCAATCATACCAACTG; positions 609 to 625) and CR4 (GTCAGGAAAACCTGCAG; inverse complement of positions 2203 to 2219). Primer CR5 (CAGGCATTGTGATGCAG, inverse complement of positions 366 to 382) was used together with CR1 to amplify a smaller fragment from the $5^{\prime}$ region of crCNGC $\alpha$ (see Fig. 2). The primer pair CO1 (TCTCCAAGGCCATAGGC) and CO2 (AATGTAATCCCCTGGGC) were used for the amplification of a fragment specific for the olfactory CNG channel of chick (W. Bönigk, unpublished result). PCR was performed with 44 cycles. For each amplification, negative controls were run to which no template DNA was added. PCR fragments were gel-purified, subcloned into pBluescript vector, and sequenced. Recombinant plasmids carrying the complete coding region of the two splice variants of the cone CNG channel (pcc CNGC $\alpha \Delta 5$-6 and pccCNGC $\alpha \Delta 6$ ) were constructed from the respective overlapping PCR fragments by making use of the internal EcoRI restriction site.

Similar experiments were performed with cDNA derived from poly $(\mathrm{A})^{+}$RNA of bovine pineal tissue. Two overlapping fragments, harboring either the $5^{\prime}$ or $3^{\prime}$ part of the coding region for rod and cone CNG channels were amplified by two sets of primers similar to those used for amplification of fragments from chick cDNA.

Analysis of genomic structure of chick cone CNG channel. A chick genomic library in $\lambda$ FIXII-vector (Stratagene, La Jolla, Ca) was screened with two cDNA probes (F5', nucleotides -39 to 926 , and $\mathrm{F}^{\prime}$ ', nucleotides 882 to 2391 of pCCG8B; Bönigk et al., 1993). Probe F5' and F3' yielded 12 and 7 positive signals, respectively. Two overlapping clones were chosen for further analysis. Clones were digested with $S a c \mathrm{I}, X b a \mathrm{I}, E c o$ RI, BamHI, SalI, and each possible combination of two endonucleases. Fragments were separated by agarose electrophoresis and those containing exon sequences were identified by Southern blotting using probes F5' and $\mathrm{F}^{\prime}$. These fragments were isolated and analyzed by PCR and sequencing using primers from the coding region.

Immunocytochemistry. Immunoreactivity was tested using a combination of techniques involving the peroxidase-antiperoxidase (PAP)- and the avidin-biotin-peroxidase (ABC) reaction (Davidoff and Schulze, 1990). Pineal organs were dissected from 1- to 3-d-old chicks and fixed by immersion in $4 \%$ paraformaldehyde in $0.1 \mathrm{M}$ phosphate buffer $(\mathrm{PB}), \mathrm{pH} 7.4$, for $1-2 \mathrm{hr}$. Fixed pineals were washed in PB, suspended in $30 \%$ sucrose overnight, and embedded in OCT medium. Horizontal sections $(12 \mu \mathrm{m})$ were cut with a cryostat and collected on chrome-gelatin-precoated glass slides. Sections were preincubated with a solution of $1.25 \%(\mathrm{v} / \mathrm{v}) \mathrm{H}_{2} \mathrm{O}_{2}$ in absolute methanol to inhibit endogenous peroxidase activity and then with $2 \%(\mathrm{v} / \mathrm{v})$ normal swine serum in PBS to block nonspecific binding sites. Sections were incubated at $4^{\circ} \mathrm{C}$ for $24 \mathrm{hr}$ with purified antibodies $63-4$ and PPcCC1 (directed against a C-terminal peptide of $\mathrm{ccCNGC} \alpha$; Bönigk et al., 1993). Antibodies were diluted 1: 20 to $1: 100$ in PBS containing $0.25 \%$ Triton X-100, $0.2 \%$ sodium azide, and $0.1 \%$ bovine serum albumin. Finally, sections were sequentially treated with biotinylated anti-rabbit IgG (Dakopatts, Copenhagen, Denmark) (1:250) added to $2 \%(\mathrm{v} / \mathrm{v})$ normal chick serum $(60 \mathrm{~min}$ at $20^{\circ} \mathrm{C}$ ), with rabbit PAP (Dakopatts) $\left(1: 200 ; 30 \mathrm{~min}\right.$ at $\left.20^{\circ} \mathrm{C}\right)$ and with $\mathrm{ABC}$ (ABC-Elite, Vector, Burlingame, CA) $\left(1: 250 ; 30 \mathrm{~min}\right.$ at $\left.20^{\circ} \mathrm{C}\right)$. For visualization of the peroxidase activity, the nickel glucose oxidase technique was used (Záborszky and Léránth, 1985). The solution contained 3',3'diaminobenzidine, glucose oxidase, glucose, ammonium chloride, and nickel(II)-sulfate hexahydrate in PB.

Bovine pineal organs were fixed by immersion in Bouin's fluid for 12 $\mathrm{hr}$ at $20^{\circ} \mathrm{C}$. Subsequently, tissue blocks were embedded in paraffin and sections $(6 \mu \mathrm{m})$ were mounted on chrome-gelatin-precoated glass slides. After being deparaffinized and rehydrated, sections were treated in the same way as described above for chick; however, biotinylated anti-rabbit IgG was added in $2 \%$ fetal calf serum/PBS. Antibody PPc15 directed against $\mathrm{b} c \mathrm{CNGC} \alpha$ (Weyand et al., 1994) was diluted 1:100.

In control experiments, sections were used in which primary, secondary, or tertiary antibodies were omitted and in which only the development of the peroxidase activity was performed. For negative controls, antibodies in their optimal dilution were preadsorbed with $20 \mu \mathrm{g} / \mathrm{ml}$ of the corresponding antigen, or, alternatively, sections were incubated with normal rabbit serum. For positive controls, sections were treated with a monoclonal antibody against hydroxyindole- $o$-methyl-transferase (HIOMT), which specifically stains pinealocytes (Sato et al., 1994).

Functional expression. The chick cone CNG channel was expressed in Xenopus oocytes and splice variants in a human embryonic kidney cell line (HEK 293). For the expression in Xenopus oocytes or HEK 293 cells, cDNA was subcloned into vectors pGEM-HE (Liman et al., 1992; gift of Dr. Tytgat, Leuven, Belgium) or pcDNAI (Invitrogen), respectively. A perfect Kozak consensus sequence preceding the start codon was introduced in all plasmids used for expression (Kozak, 1984). cRNA was synthesized in vitro using the respective linearized plasmid cDNA as template. In vitro transcription of cDNA, injection of cRNA into oocytes, and preparation of oocytes for patch-clamp experiments were performed as described (Bönigk et al., 1993, and references therein). Expression in HEK 293 cells was performed as described in Baumann et al. (1994). Dose-response relations of cGMP-activated currents were studied in excised inside-out patches of plasma membrane as described for oocytes (Altenhofen et al., 1991; Bönigk et al., 1993) and HEK 293 cells (Baumann et al., 1994). The solution in the pipette and the perfusion medium contained (in $\mathrm{mM}$ ): $100 \mathrm{KCl}, 10$ HEPES-KOH, pH 7.4, and 10 EGTA-KOH. Leak currents recorded in the absence of cGMP were subtracted from currents measured in the presence of the ligand (5-1000 $\mu \mathrm{M}$ cGMP).

The CaM sensitivity of cGMP-activated currents was determined in either oocytes ( $c c \mathrm{CNGC} \alpha$ ) or HEK 293 cells ( $c$ CNGC $\alpha \Delta 5-6)$. The experimental procedures for either expression system were similar. For HEK 293 cells, KCl-based solutions were used; however, to suppress $\mathrm{Ca}^{2+}$-activated $\mathrm{Cl}^{-}$currents in the oocyte membrane, $\mathrm{KCl}$ was replaced by $\mathrm{K}^{+}$-gluconate. An intrapipette salt bridge similar to that described by Baumann et al. (1994) was used. The basic solutions in the pipette and the bath contained (in mM): $100-120 \mathrm{~K}^{+}$salt, 10 HEPES-KOH, $\mathrm{pH} 7.4$, and 
A

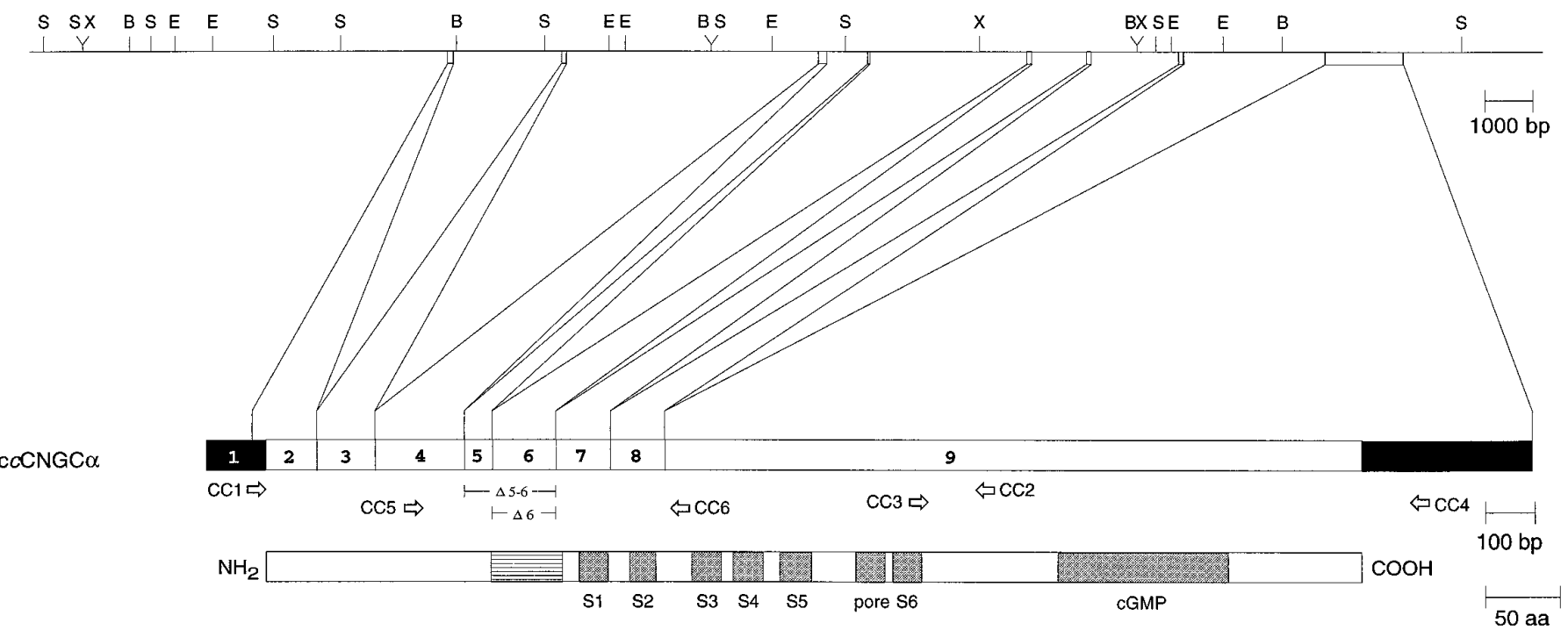

hrCNGC $\alpha$

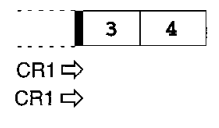

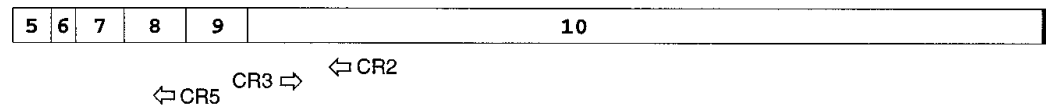

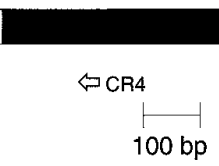

Figure 1. Gene structure of the chick cone CNG channel. $A$, Top, Restriction map of chromosomal DNA encompassing exons 1-9 of the chick cone CNG channel gene. B, BamHI; E, EcoRI; $S, S a c \mathrm{I} ; X, X b a \mathrm{I}$. A, Bottom, Comparison of the exon structure of the chick cone CNG channel (ccCNGC $\alpha$ ) and the human rod CNG channel (h $r$ CNGC $\alpha$; Dhallan et al., 1992) with the transmembrane topology of CNG channels. Solid and open boxes, respectively, refer to noncoding and coding regions of exons. Gray boxes refer to transmembrane segments S1-S6, the pore region, and the cGMP-binding site (cGMP); the striped box indicates the highly charged domain in the N-terminal region of the polypeptide. The arrows refer to primer pairs CC1/CC2, CC3/CC4, and CC5/CC6 used for amplification of cone-specific cDNA fragments, or to the primer pairs CR1/CR2, CR3/CR4, and CR1/CR5 used for amplification of rod-specific cDNA fragments. $B$, Nucleotide sequence (with splice junction donor and acceptor sequences of exon/intron boundaries in the cDNA) and deduced amino acid sequence of $c \mathrm{CNGC} \alpha$. Intron sequences at intron/exon boundaries are given in small letters. Numbering of nucleotide positions refers to the cDNA sequence and begins with +1 at the adenine nucleotide of the start codon. Figure continues.

the indicated additions of EGTA, nitrilotriacetic acid (NTA)/Ca ${ }^{2+}$ buffer, $\mathrm{CaM}$, and cGMP.

After excision, the membrane patch first was perfused for 1-2 min with a solution containing $10 \mathrm{~mm}$ EGTA to remove all endogenous CaM that might have been bound to the channel in the oocyte or the HEK 293 cell. Subsequently, leak currents were recorded in a solution containing $50 \mu \mathrm{M}$ free $\mathrm{Ca}^{2+}\left(0.8 \mathrm{mM} \mathrm{Ca}^{2+}\right.$ salt and $2 \mathrm{~mm}$ NTA). Finally, current-voltage $(I-V)$ relations were recorded in $50 \mu \mathrm{M}$ free $\mathrm{Ca}^{2+}$ with and without $\mathrm{CaM}$ $(0.6-1.2 \mu \mathrm{M})$ at saturating $(500 \mu \mathrm{M})$ and nonsaturating $(20 \mu \mathrm{M})$ concentrations of cGMP.

\section{RESULTS}

\section{Characterization of CNG channel transcripts and organization of the chick cone CNG channel gene}

Expression of CNG channels in pineal tissue was examined by PCR, using as template first-strand cDNA synthesized from pineal poly $\left(\mathrm{A}^{+}\right)$RNA. Overlapping cDNA fragments were amplified by two sets of primers specific for the $\mathrm{CNG}$ channel $\alpha$-subunit of either chick rod $(\mathrm{crCNGC} \alpha)$ or cone photoreceptor $(\mathrm{ccCNGC} \alpha)$ (Bönigk et al., 1993). No amplification products could be detected using primers for the $\mathrm{CNG}$ channel $\alpha$-subunit of chick olfactory epithelium $(\operatorname{coCNGC} \alpha)$, indicating that only photoreceptor $\mathrm{CNG}$ channels are expressed in the pineal.

Primer pairs were chosen that allow amplification of the entire coding region in two overlapping fragments (for positions of primers, see Fig. $1 A$ ). PCR with the $\mathrm{c} c \mathrm{CNGC} \alpha$-specific primer pair $\mathrm{CC} 1 / \mathrm{CC} 2$ produced two fragments, which were both shorter than expected from the structure of the cDNA cloned from retina (clone pCCG8B of Bönigk et al., 1993). Sequencing of cloned fragments revealed that segments of different length were missing in the region coding for the intracellular $\mathrm{N}$-terminal domain (Fig. $2 A$ ). Amplification with primer pair $\mathrm{CC} 3 / \mathrm{CC} 4$ produced a single fragment that matched in size and sequence the corresponding fragment amplified from pCCG8B. These results suggest that two alternatively spliced forms of $\mathrm{ccCNGC} \alpha$ are expressed in the pineal organ.

To exclude possible PCR artifacts, we elucidated the structure of the cone CNG channel gene. Comparison of genomic and cDNA sequences revealed that the $c c \mathrm{CNGC} \alpha$ gene is composed of at least nine exons (Fig. $1 A$ ). We cannot exclude the possibility that additional exons exist in the $5^{\prime}$ noncoding region. Consensus sequences of donor/acceptor splice sites are observed at most of the exon/intron boundaries (Fig. 1B). The boundaries of exon 5 and 6 are identical with the positions of deletions. Thus, alternative splicing in the pineal produces an internal in-frame deletion of either 44 or 62 codons belonging to exons 6 or 5 and 6 , respectively. The longer channel form, designated $\operatorname{ccCNGC} \alpha \Delta 6$, encodes a polypeptide of 691 amino acid residues with a calculated $M_{\mathrm{w}}$ of $79.5 \mathrm{kDa}$; the shorter channel form, designated c $c$ CNGC $\alpha \Delta 5-6$, encodes a polypeptide of 673 amino acid residues with a $M_{\mathrm{w}}$ of $77.4 \mathrm{kDa}$.

The genomic organizations of the human $\operatorname{rod}(\mathrm{h} r \mathrm{CNGC} \alpha$; Dhallan et al., 1992) and chick cone CNG channels are similar in that the $\mathrm{N}$-terminal third of both polypeptides is encoded by seven small exons, whereas the C-terminal two thirds, following transmembrane segment S2, are encoded by a single large exon (Fig. 
B

\section{$-88$} 92 93 28 51 


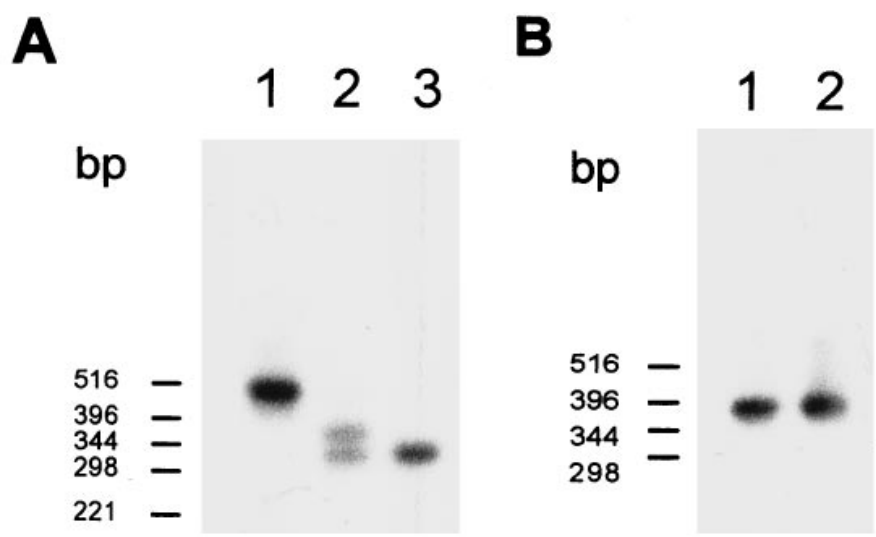

Figure 2. Transcript structure of $c c \mathrm{CNGC} \alpha$ and $\operatorname{con} \mathrm{CNC} \alpha$. Blot hybridization of PCR fragments amplified from $\mathrm{cDNA}$ with $\mathrm{cc} \mathrm{CNGC} \alpha$-specific $(A)$ and $\operatorname{coNGC} \alpha$-specific $(B)$ primer pairs $(\mathrm{CC} 5 / \mathrm{CC} 6$ and $\mathrm{CR} 1 / \mathrm{CR} 5$, respectively). The blot was hybridized with radioactively labeled DNA probes amplified with the same primer set and using cDNA clones pCCG6 and pCCG8B (Bönigk et al., 1993) as templates. Lanes in A: 1, retina; 2, pineal; 3 , testis. Lanes in $B: 1$, retina; 2 , pineal. For negative control PCR, no hybridization signals were detected (data not shown).

$1 A, B)$. Exons $3,4,5,8,9$, and 10 of $\mathrm{h} r \mathrm{CNGC} \alpha$ correspond to exons $2,3,5,7,8$, and 9 of c $c \mathrm{CNGC} \alpha$, respectively. Exons 6 and 7 of $\mathrm{h} r \mathrm{CNGC} \alpha$ correspond to a single exon 6 in the $\mathrm{c} c \mathrm{CNGC} \alpha$ gene. The equivalent of exon 4 in the $c c \mathrm{CNGC} \alpha$ gene is missing in the $\mathrm{h} r \mathrm{CNGC} \alpha$ gene (see below).

With each of the $\operatorname{crCNGC} \alpha$-specific primer pairs CR1/CR2 and CR3/CR4 (see Fig. 1 $A$ ), single fragments were amplified from retinal and pineal cDNA, which matched in size and nucleotide sequence the corresponding fragments amplified from cDNA encoding $\mathrm{crCNGC} \alpha$ (clone pCCG6 of Bönigk et al., 1993) (also see Fig. $2 B$ ). This result demonstrates that no splice form of the rod $\mathrm{CNG}$ channel exists in either retina or pineal.

The cellular responses of pinealocytes and their control by neural pathways are fundamentally different in mammals and birds (Takahashi et al., 1989). Therefore, we also examined the expression of $\mathrm{CNG}$ channels in bovine pineal tissue. Fragments encoding CNG channel $\alpha$-subunits of rod and cone photoreceptors could be amplified using bovine pineal cDNA (data not shown), which were identical to the fragments amplified from cloned cDNA (clone pCGTE of Weyand et al., 1994, and clone pRCG1 of Kaupp et al., 1989). Thus, in bovine pineal, only the respective photoreceptor forms of channel $\alpha$-subunits exist.

\section{Expression of splice variants in other tissues}

To examine whether pineal splice forms of $\mathrm{ccCNGC} \alpha$ occur in other tissues as well, primer pair CC5/CC6 instead of $\mathrm{CC} 1 / \mathrm{CC} 2$ was used, which amplifies smaller fragments of the respective region and thereby facilitates detection of bands with a different size. Amplification of pineal cDNA with primer pair CC5/CC6 produced two fragments of $324 \mathrm{bp}$ and $378 \mathrm{bp}$ (Fig. 2A, lane 2), whereas only a single fragment of 510 bp was amplified from retinal cDNA (Fig. $2 A$, lane 1 ), which was identical to the corresponding fragment amplified from cloned cDNA of cc CNGC $\alpha$. This result demonstrates that the pineal splice variants of ${ }^{c} c \mathrm{CNGC} \alpha$ are not expressed in the retina.

Recently, it has been reported that the $\alpha$-subunit of the cone CNG channel is expressed in bovine spermatozoa (Weyand et al., 1994). Therefore, we analyzed the transcript structure of CNG channels expressed in chick testis with the same set of primers. A single fragment of $324 \mathrm{bp}$ was amplified (Fig. 2A, lane 3 ). This fragment was identical to the shorter fragment amplified from pineal cDNA, suggesting that one of the pineal forms of cc CNGC $\alpha$ is also expressed in chick spermatozoa.

Figure $2 B$ illustrates the absence of any splice variants of the rod $\mathrm{CNG}$ channel in the pineal and the retina.

\section{Immunocytochemical localization}

Using antibody 63-4 directed against a C-terminal peptide from cc CNGC $\alpha$ (Bönigk et al., 1993), immunoreactivity was revealed in chick pineal organs. Antibody 63-4 stained the apical region of most cells that reach into the lumen of the pineal follicle (Fig. $3 A, B)$. These cells most likely represent modified pineal photoreceptors consisting of a rudimentary outer segment and an inner segment. Immunoreactivity was also detected in the basal part of the follicle, where para-follicular pinealocytes are localized (Voisin et al., 1988). When antibody 63-4 was omitted (data not shown) or was preincubated with the corresponding antigen (Fig. $3 E$ ), no staining of chick follicular pinealocytes was observed. Similar results were obtained with another antibody against the same channel peptide (PPcCC1; data not shown).

Antibody PPc15, directed against the C-terminal domain of the bovine cone $\mathrm{CNG}$ channel $\mathrm{b} c \mathrm{CNGC} \alpha$ (Weyand et al., 1994), stained few circular or ellipsoid structures in the lateral aspects, i.e., the cortex, of the bovine pineal (Fig. 3C,D). Some of these structures $(\varnothing \approx 4-5 \mu \mathrm{m})$ are smaller than the majority of bovine pinealocytes $(\varnothing \approx 15-18 \mu \mathrm{m})$. Small cellular structures were also recognized by an HIOMT antibody that specifically stains pinealocytes. It is difficult to decide whether these structures represent a subset of small pinealocytes or subcellular compartments, which could indicate a regional expression of the antigen within a cell. When antibody PPc15 was omitted (Fig. $3 F$ ) or was preincubated with the corresponding antigen (data not shown), no staining of cells in the periphery of the bovine pineal was observed.

\section{Functional expression}

When injected into Xenopus oocytes, cRNA derived from clone pcc CNGC $\alpha \Delta 6$ did not give rise to cGMP-stimulated currents. Expression in a human embryonic kidney cell line (HEK 293) was also not successful. Antibody PPcCC1 that specifically recognizes cc CNGC $\alpha$ (Bönigk et al., 1993) only weakly stained a few transfected HEK 293 cells. We did not further pursue heterologous expression of $c c \mathrm{CNGC} \alpha \Delta 6$. Expression of the shorter splice variant $c c \mathrm{CNGC} \alpha \Delta 5-6$ in oocytes or HEK 293 cells gave rise to cGMP-stimulated channel activity.

Figure 4 shows a series of macroscopic $I-V$ recordings from inside-out patches of HEK 293 cells at different concentrations of cGMP. Mean values for half-maximal activation $K_{1 / 2} \pm$ SD (number of experiments) and the Hill coefficient $n$ determined from the Hill equation $I / I_{\max }=C_{\mathrm{cG}}^{\mathrm{n}} /\left(C_{\mathrm{cG}}^{\mathrm{n}}+K_{1 / 2}^{\mathrm{n}}\right)$ for ccCNGC $\alpha \Delta 5$-6 were $24.1 \pm 8.1 \mu \mathrm{M}, n=1.8 \pm 0.5(10)$ at $-80 \mathrm{mV}$, and $14.6 \pm 6.2 \mu \mathrm{M}$, $n=1.9 \pm 0.6(10)$ at $+80 \mathrm{mV}$. Mean values for $K_{1 / 2}$ of the chick ccCNGC $\alpha$ were $47 \pm 8.5 \mu \mathrm{M}, n=2.1 \pm 0.5(6)$, and $23.5 \pm 9.2 \mu \mathrm{M}$, $n=2.1 \pm 0.5(6)$ at $-80 \mathrm{mV}$ and $+80 \mathrm{mV}$, respectively.

\section{Modulation by $\mathrm{Ca}^{2+} / \mathrm{CaM}$}

Exon 4 of $c c \mathrm{CNGC} \alpha$ encodes a segment of 61 amino acid residues that is highly homologous to a slightly shorter N-terminal region in $\mathrm{CNG}$ channels of OSNs. Sequence alignment of this region from two cone-specific and two olfactory-specific CNG channels is shown in Figure 5. In the rat olfactory CNG channel, this segment carries a CaM-binding site (Liu et al., 1994), which provides the channel with a pronounced $\mathrm{CaM}$ sensitivity. In contrast, the 

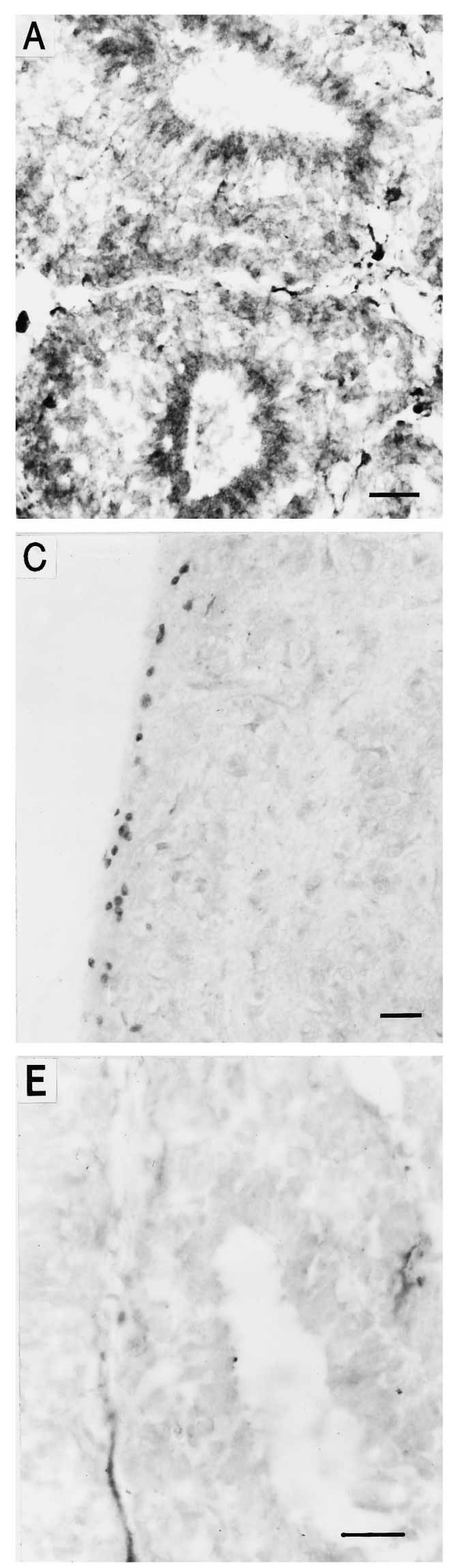
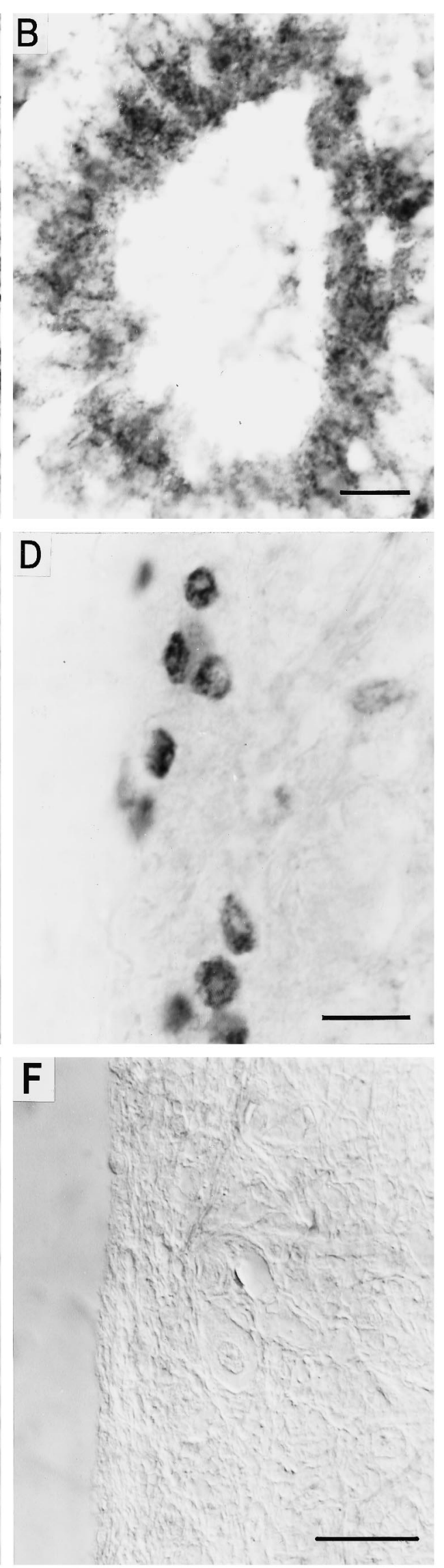

Figure 3. Immunohistochemical localization of cone $\mathrm{CNG}$ channel in chick and bovine pineal organ. $A$, Horizontal cryostat section $(12 \mu \mathrm{m})$ of the chick pinea organ stained with antibody 63-4 and visualized by peroxidase reaction. Cells of two pineal follicles are labeled, whereas pinealocytes outside the follicle are stained less prominently. Scale bar, 20 $\mu \mathrm{m}$. $B$, Same as in $A$ at higher magnification. Scale bar, $10 \mu \mathrm{m}$. $C$, Horizontal paraffin section $(6 \mu \mathrm{m})$ of the bovine pineal organ stained with antibody PPc15 and visualized by peroxidase reaction. PPc15 immunoreactivity is observed in only a few cells in the cortex of the pineal, whereas cells of the medullary part of the organ are not labeled. Scale bar, $20 \mu \mathrm{m}$. $D$, Same as in $C$ at higher magnification. Scale bar, $10 \mu \mathrm{m}$. E, Control section of chick pineal. Specific staining is abolished after preincubation of antibody 63-4 with the respective antigenic peptide $(20 \mu \mathrm{g} /$ $\mathrm{ml})$. Scale bar, $20 \mu \mathrm{m}$. $F$, Control section of bovine pineal. No staining was observed when the primary antibody PPc15 was omitted. Picture was taken with Nomarski optics. Scale bar, $20 \mu \mathrm{m}$. 
Figure 4. Activation of splice variant cc CNGC $\alpha \Delta 5-6$ by cGMP. Series of $I-V$ recordings in the presence of different cGMP concentrations. Inside-out patch of HEK 293 cells transfected with plasmid pccCNGC $\alpha \Delta 5-6$. The inset shows the dose-response relation at $-60 \mathrm{mV}$. The $K_{1 / 2}^{1 / 2}$ value was $30 \mu \mathrm{M}$, and the Hill coefficient was $\mathrm{n}=1.8$. The cGMP concentrations were trace 1, $5 \mu \mathrm{M} ; 2,10 \mu \mathrm{M} ; 3,20 \mu \mathrm{M} ; 4,30 \mu \mathrm{M} ; 5,50 \mu \mathrm{M}$; $6,80 \mu \mathrm{M} ; 7,100 \mu \mathrm{M} ; 8,300 \mu \mathrm{M} ; 9,1000 \mu \mathrm{M}$.
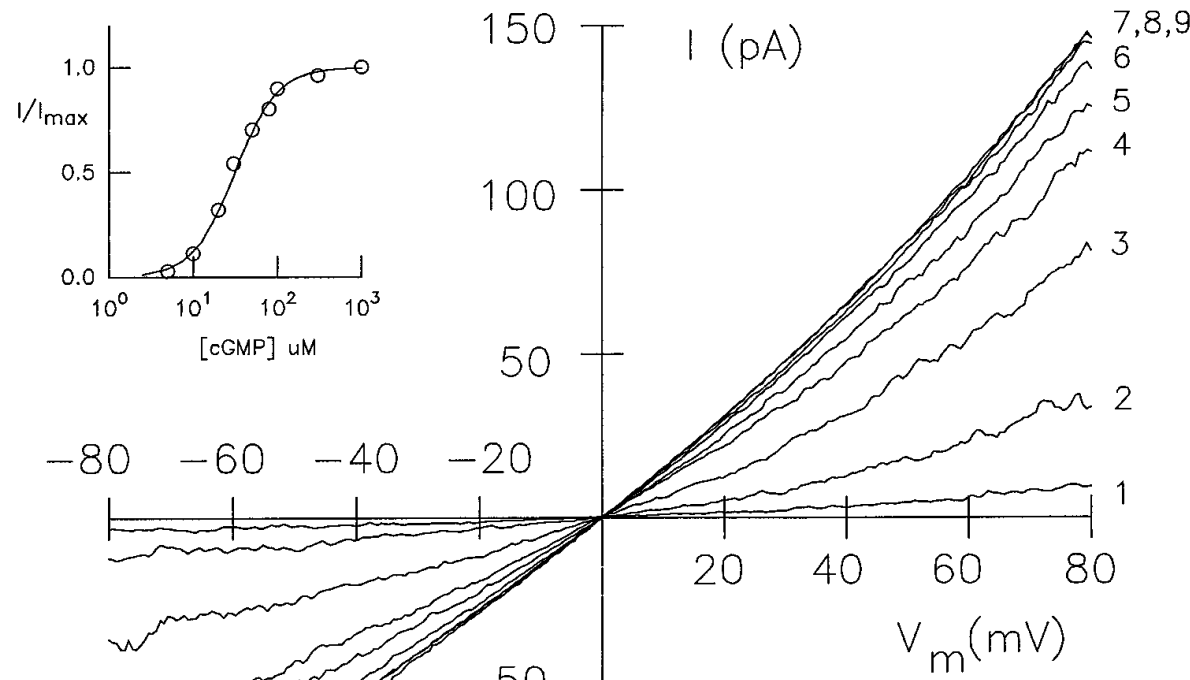

$\operatorname{ccCNGC} \alpha$ bcCNGC $\alpha$ $\operatorname{roCNGC} \alpha$

foCNGC $\alpha$

$\star \star 0 \star \star 0 \quad 0 \star \star$ SQGP - TRLSRL I ISLRAWSARHLHQEDQRPDS FLER FRGAELQEVSSRESHVQFNVGSQEPPDRGRS RRGRGGFQR IVR L VGVIRDWANRNFREEEPR P DSFLERFR GPEL QTVTTHQG - . - ......... ET QRRPLARLVNLVLSLREWAHKSLVETEQR PDS FLER FRG PQAANDQSAAPA . . . . . . .

$+\Delta+h+h h h+\Delta+$

Figure 5. Sequence comparison of regions containing a CaM-binding motif in cone and olfactory CNG channels. Sequence alignment of exon 4-encoded region of $c c \mathrm{CNGC} \alpha$ with a homologous region of CNG channels from bovine cone photoreceptor (bcCNGC $\alpha$; Weyand et al., 1994), rat olfactory epithelium (roCNGC $\alpha$; Dhallan et al., 1990), and fish olfactory epithelium (foCNGC $\alpha$; Goulding et al., 1992). Arrowheads indicate the two aromatic or long-chain amino acid residues; + indicates the basic residues; and $h$ refers to hydrophobic residues in the amphiphilic domain of the CaM-binding site. The stars above the sequences indicate that at least three residues at this position are identical; open circles indicate that at least three residues at this position are conserved.

$\alpha$-subunit of the rod CNG channel, which is lacking this segment, requires for $\mathrm{CaM}$ sensitivity a $240 \mathrm{kDa}$ polypeptide (Hsu and Molday, 1993) that has been identified as $\beta$-subunit (Körschen et al., 1995). The CaM-binding motif is characterized by two aromatic or long-chain residues separated by 12 amino acid residues and by a basic amphiphilic structure (Fig. 5B) (O'Neil and DeGrado, 1990; Ikura et al., 1992). A CaM-binding motif suggests that the activity of cone similar to olfactory CNG channels may be modulated by binding of $\mathrm{CaM}$ to the $\alpha$-subunit.

This prompted us to examine the modulation of cGMPactivated currents of the cone $\mathrm{CNG}$ channel by $\mathrm{Ca}^{2+} / \mathrm{CaM}$. Figure $6 A$ shows an experiment with $c c \mathrm{CNGC} \alpha$. In the presence of saturating cGMP concentrations $(500 \mu \mathrm{M})$, only a small or no difference was observed between current recordings with or without $1.2 \mu \mathrm{M} \mathrm{CaM}$ and with $50 \mu \mathrm{M} \mathrm{Ca}{ }^{2+}$ in the perfusion medium (Fig. $6 A$, traces 1 and 2 ). When the cGMP concentration $(20 \mu \mathrm{M})$ roughly equalled the $K_{1 / 2}^{1 / 2}$ value of channel activation, however, the current was suppressed almost twofold by $\mathrm{Ca}^{2+} / \mathrm{CaM}$ (Fig. $6 \mathrm{~A}$, traces 3 and 4 ). The current suppression by $\mathrm{Ca}^{2+} / \mathrm{CaM}$ was reversible. When the patch was perfused for a few minutes with EGTA and no CaM, the current amplitude recovered and usually reached the value before perfusion with $\mathrm{CaM}$. Occasionally, the current level did not recover completely. Because the saturating current was also decreased, this effect was not attributable to incomplete removal of $\mathrm{CaM}$ but rather was attributable to unspecific run-down of patch current.

We also examined whether channel modulation by $\mathrm{Ca}^{2+} / \mathrm{CaM}$ is altered in the splice variant $c c \mathrm{CNGC} \alpha \Delta 5-6$. Figure $6 B$ shows $I-V$ recordings with cc CNGC $\alpha \Delta 5-6$ similar to those shown in $A$ for $\mathrm{cc} \mathrm{CNGC} \alpha$. The current at a subsaturating cGMP concentration was reduced significantly in the presence of CaM (600 nM), similar to the effect observed with ccCNGC $\alpha$ (Fig. $6 B$, traces 3 and 4 ). At a saturating cGMP concentration, CaM had no effect (Fig. $6 B$, traces 1 and 2 ). In conclusion, the significantly shorter region 

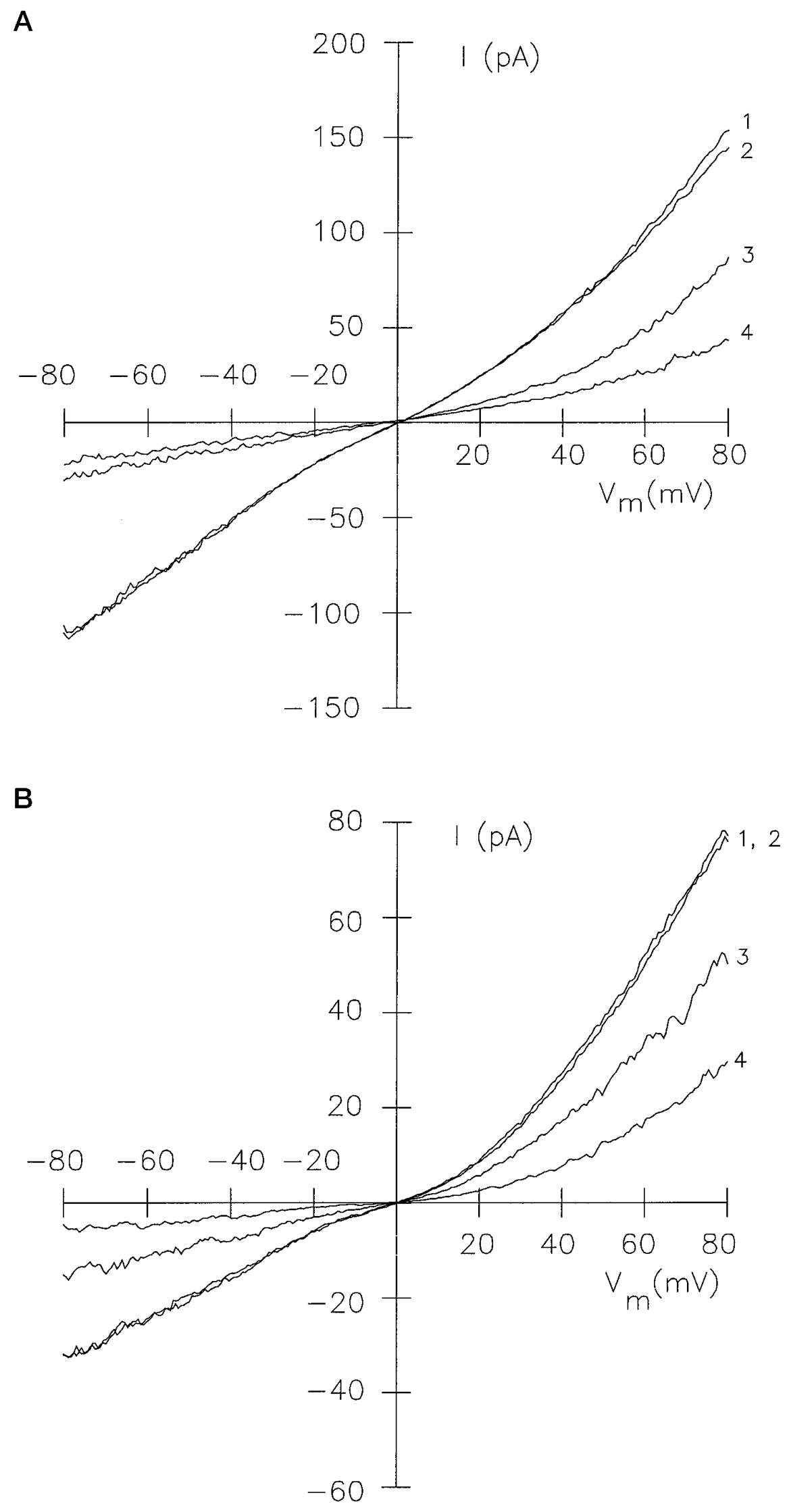

Figure 6. Modulation of channel activity by $\mathrm{Ca}^{2+}$ / CaM. $A$, Effect of $\mathrm{Ca}^{2+} / \mathrm{CaM}$ on the cGMPactivated current of $\mathrm{ccCNGC} \alpha$ expressed in Xenopus oocytes (inside-out patch). The bath solutions contained $120 \mathrm{~mm} \mathrm{~K}^{+}$-gluconate, $10 \mathrm{~mm}$ HEPES$\mathrm{KOH}, 50 \mu \mathrm{M} \mathrm{Ca}^{2+}$, and the following additions: 500 $\mu \mathrm{M}$ cGMP (trace 1); $500 \mu \mathrm{M}$ cGMP and $1.2 \mu \mathrm{M}$ CaM (trace 2); $20 \mu \mathrm{M}$ cGMP (trace 3); $20 \mu \mathrm{M} \mathrm{cGMP}$ and $1.2 \mu \mathrm{M}$ CaM (trace 4). B, Effect of $\mathrm{Ca}^{2+} / \mathrm{CaM}$ on the cGMP-activated current of splice variant cc CNGC $\alpha \Delta 5-6$ expressed in HEK 293 cells. Same conditions as in $A$ except that the CaM concentration was $600 \mathrm{nM}$, and the solution was based on $\mathrm{KCl}$ instead of $\mathrm{K}^{+}$-gluconate. 
Table 1. Modulation of $K_{1 / 2}$ values by $\mathrm{Ca}^{2+} /$ calmodulin

\begin{tabular}{|c|c|c|c|c|c|c|c|}
\hline & \multirow{3}{*}{$\begin{array}{l}\text { Experiment } \\
\text { no. }\end{array}$} & \multicolumn{6}{|c|}{ Values of $K_{1 / 2}(\mu \mathrm{M})^{a}$} \\
\hline & & \multicolumn{3}{|c|}{$-80 \mathrm{mV}$} & \multicolumn{3}{|c|}{$+80 \mathrm{mV}$} \\
\hline & & $-\mathrm{CaM}$ & $+\mathrm{CaM}$ & $\Delta K_{1 / 2}$ & $-\mathrm{CaM}$ & $+\mathrm{CaM}$ & $\Delta K_{1 / 2}$ \\
\hline & 2 & 42 & 53 & 11 & 15 & 25 & 10 \\
\hline & 3 & 38 & 55 & 17 & 17 & 35 & 18 \\
\hline \multirow[t]{2}{*}{$\operatorname{ccCNGC} \alpha \Delta 5-6$} & 1 & 25 & 55 & 30 & 15 & 33 & 18 \\
\hline & 4 & 38 & 50 & 12 & 27 & 33 & 6 \\
\hline
\end{tabular}

${ }^{a}$ Values were determined from at least four cGMP concentrations.

between the putative CaM-binding site and the first membranespanning segment $\mathrm{S} 1$ in the pineal form of the cone CNG channel does not alter the $\mathrm{Ca}^{2+} / \mathrm{CaM}$ effect.

Table 1 summarizes modulation of $K_{1 / 2}$ values by $\mathrm{Ca}^{2+} / \mathrm{CaM}$ from several experiments with $\mathrm{ccCNGC} \alpha$ and $c c \mathrm{CNGC} \alpha \Delta 5-6$. The effect was small but was observed consistently in all experiments and was of similar size as that reported for the rod CNG channel (Hsu and Molday, 1993; Gordon et al., 1995; Körschen et al., 1995; Nakatani et al., 1995).

\section{DISCUSSION}

\section{Expression of CNG channels in the pineal}

Here we demonstrate by PCR analysis of the respective cDNA that the $\alpha$-subunit of the cone photoreceptor CNG channel itself or two shorter splice variants are expressed in the pineal organs of bovine and chick, respectively.

Antibodies against the chick cone $\mathrm{CNG}$ channel recognize the majority of modified photoreceptors in the chick pineal follicle, although the immunoreactivity seems to be weaker as compared with cone photoreceptors (Bönigk et al., 1993, their Fig. 5). In the bovine, only few cells in the periphery of the pineal are labeled by an antibody specific for the bovine cone channel. A similar labeling pattern has also been observed in the rat pineal with an antibody directed against recoverin (Korf et al., 1992). Although rod CNG channel-specific sequences can be amplified from pineal cDNA of chick and bovine (Distler et al., 1994; Schaad et al., 1995), two different antibodies directed against the bovine rod CNG channel failed to specifically mark pineal tissue (data not shown). This discrepancy and the moderate staining of the chick pineal with the cone channel-specific antibody probably arises from a low channel density. This conclusion is supported by studies that estimated that excised membrane patches of chick pinealocytes contain 3-10 copies of a CNG channel (Dryer and Henderson, 1991, 1993). This channel density is roughly 100-fold lower than in the outer segment membrane of rod photoreceptors, but of the same order as that observed in the inner segment of rod (Matthews and Watanabe, 1988; Torre et al., 1992) and the synaptic region of cone (Rieke and Schwartz, 1994) photoreceptors. In these regions, CNG channels also escape unequivocal detection by immunohistochemical methods (F. Müller, unpublished observations).

Previously, components of the light-dependent enzyme cascade of retinal photoreceptors, such as arrestin, recoverin, rhodopsin kinase, phosducin, guanylate cyclase, and cGMP-specific phosphodiesterase, have been demonstrated in the pineal (Kalsow and Wacker, 1978; Somers and Klein, 1984; Korf et al., 1985;
Palczewski et al., 1990; Reig et al., 1990; Korf et al., 1992; Carcamo et al., 1995; Yang et al., 1995; for reviews, see Lolley et al., 1992; Korf, 1994). Some polypeptides have been identified by cloning or isotype-specific antibodies. For example, pineal arrestin and phosducin are virtually identical with their rod photoreceptor forms (Abe and Shinohara, 1990; Abe et al., 1990), whereas the cone-specific PDE is present in rat and bovine pineal (Carcamo et al., 1995). Pinopsin, a unique rhodopsin-like molecule, is expressed exclusively in the pineal (Okano et al., 1994; Max et al., 1995). Our results demonstrate that for the CNG channel both rod and cone photoreceptor isoforms and some splice variants co-exist in the pineal. In conclusion, the pineal polypeptide inventory seems to be rather complex, raising several intriguing questions. Are the rod- and cone-specific isoforms of signaling components expressed in the same cells or in different subtypes of pinealocytes? Do pineal signaling pathways mix components from rod and cone photoreceptors or are these segregated to different cellular regions where they subserve diverse functions? It will be an interesting and formidable task for future research to answer these questions with immunohistochemical techniques on a cellular or subcellular level.

\section{Physiological function}

The existence of different splice forms and the dissimilar expression pattern of the cone $\mathrm{CNG}$ channel in bovine and chick pineal could reflect the difference in the regulation of pineal function in mammals and birds. Modified pinealocytes of birds and lower vertebrates retained light sensitivity, and the cone CNG channel is likely to be involved in light-dependent signaling in rudimentary outer segments. At sites of synaptic input by VIP and NE, which are known to increase cellular cGMP concentrations, the cone CNG channel, because of its high $\mathrm{Ca}^{2+}$ permeability (Perry and McNaughton, 1991; Frings et al., 1995; Picones and Korenbrot, 1995), could serve as a $\mathrm{Ca}^{2+}$ entry pathway and mediate the rise in $\left[\mathrm{Ca}^{2+}\right]_{\mathrm{i}}$ by VIP (D'Souza and Dryer, 1994) or other neurotransmitters. This may even be the exclusive function in mammalian pinealocytes that do not respond to light.

The splice variants of the cone CNG channel in the chick pineal are lacking a highly charged segment in the $\mathrm{N}$-terminal region encoded by exon 6. This segment is present in CNG channels from both rod and cone photoreceptors (Bönigk et al., 1993) but is much less pronounced in olfactory $\mathrm{CNG}$ channels. In this respect, the two splice variants are more akin to the olfactory $\mathrm{CNG}$ channel. The N-terminal region, by allosteric interaction with the ligand binding site in the $\mathrm{C}$ terminus, co-determines the ligand sensitivity (Goulding et al., 1994), which is higher in olfactory than 
in photoreceptor CNG channels. Therefore, the shorter $\mathrm{N}$-terminal region in the splice variant most likely is responsible for the twofold higher ligand sensitivity compared with the complete cone $\mathrm{CNG}$ channels. Other functions of this region, if any, are not known; it may control assembly of the multimeric channel complex or direct expression of splice variants to different sites such as, for example, the rudimentary outer segment or the synaptic region of the cell.

\section{Modulation by $\mathrm{Ca}^{2+} / \mathrm{CaM}$}

It has been shown previously that rod and olfactory $\mathrm{CNG}$ channels are modulated by $\mathrm{Ca}^{2+} / \mathrm{CaM}$ (Hsu and Molday, 1993; Chen and Yau, 1994), whereas a similar modulation has not yet been demonstrated for the native cone $\mathrm{CNG}$ channel. $\mathrm{Ca}^{2+} / \mathrm{CaM}$ can decrease the cAMP sensitivity of the olfactory CNG channel by almost 20-fold (Chen and Yau, 1994). A segment of roughly 16 residues in the $\mathrm{N}$-terminal region has been identified as a CaMbinding site in the $\alpha$-subunit of the rat olfactory CNG channel (Liu et al., 1994). The effect of CaM on the rod CNG channel is at least 10-fold weaker (Hsu and Molday, 1993; Gordon et al., 1995; Nakatani et al., 1995) and requires the $240 \mathrm{kDa} \beta$-subunit (Hsu and Molday, 1993; Körschen et al., 1995). Thus, the extent and site of modulation by $\mathrm{Ca}^{2+} / \mathrm{CaM}$ is different for rod and olfactory CNG channels.

The region of the cone $\mathrm{CNG}$ channel $\alpha$-subunit encoded by exon 4 is highly homologous to a region of the olfactory $\mathrm{CNG}$ channel that harbors the CaM-binding site. At first sight, both conservation of this motif and the moderate yet significant CaM sensitivity of chick cone $\alpha$-subunit would argue for a regulatory role of $\mathrm{Ca}^{2+} / \mathrm{CaM}$ in vivo. Several observations, however, caution against a rash interpretation. First, although the binding motifs in cone and olfactory CNG channels are rather similar, the $\mathrm{Ca}^{2+}$ / $\mathrm{CaM}$ effect in the cone $\alpha$-subunit is much smaller than in the olfactory $\alpha$-subunit. In fact, it is as small as that in the native rod CNG channel (Gordon et al., 1995; Körschen et al., 1995; Nakatani et al., 1995). CaM-binding motifs similar to those in the $\alpha$-subunits of cone or olfactory CNG channels, however, cannot be identified in the $\beta$-subunit that confers CaM sensitivity to the rod CNG channel (Hsu and Molday, 1993; Körschen et al., 1995). This suggests that sites for $\mathrm{CaM}$ recognition must be significantly different in $\alpha$ - and $\beta$-subunits. Finally, no modulation by $\mathrm{Ca}^{2+} /$ $\mathrm{CaM}$ was detected for the native cone $\mathrm{CNG}$ channel from catfish (Haynes and Stotz, 1996) and the heterologously expressed bovine cone CNG channel $\alpha$-subunit (F. Müller, unpublished observations).

Recently, Gordon et al. (1995) provided some preliminary evidence that an unknown cellular factor, in addition to or instead of CaM, may control CNG channel activity in rod photoreceptors. An unknown factor may also control the activity of the cone CNG channel by binding to a site that can be used promiscuously by $\mathrm{CaM}$ in some but not all species. It will be an important task for future research to characterize the physiological significance of this putative CaM-binding motif.

\section{REFERENCES}

Abe T, Nakabayashi H, Tamada H, Takagi T, Sakuragi S, Yamaki K, and Shinohara T (1990) Analysis of the human, bovine and rat $33 \mathrm{kDa}$ proteins and cDNA in retina and pineal gland. Gene 91:209-215.

Abe T, Shinohara T (1990) S-antigen from the rat retina and pineal gland have identical sequences. Exp Eye Res 51:111-112.

Altenhofen W, Ludwig J, Eismann E, Kraus W, Bönigk W, Kaupp UB (1991) Control of ligand specificity in cyclic nucleotide-gated channels from rod photoreceptors and olfactory epithelium. Proc Natl Acad Sci USA 88:9868-9872.
Baumann A, Frings S, Godde M, Seifert R, Kaupp UB (1994) Primary structure and functional expression of a Drosophila cyclic nucleotidegated channel present in eyes and antennae. EMBO J 13:5040-5050.

Bönigk W, Altenhofen W, Müller F, Dose A, Illing M, Molday RS, Kaupp UB (1993) Rod and cone photoreceptor cells express distinct genes for cGMP-gated channels. Neuron 10:865-877.

Bradley J, Li J, Davidson N, Lester HA, Zinn K (1994) Heteromeric olfactory cyclic nucleotide-gated channels: a new subunit that confers increased sensitivity to cAMP. Proc Natl Acad Sci USA 91:8890-8894.

Carcamo B, Hurwitz MY, Craft CM, Hurwitz RL (1995) The mammalian pineal expresses the cone but not the rod cyclic GMP phosphodiesterase. J Neurochem 65:1085-1092.

Chen T-Y, Peng Y-W, Dhallan RS, Ahamed B, Reed RR, Yau K-W (1993) A new subunit of the cyclic nucleotide-gated cation channel in retinal rods. Nature 362:764-767.

Chen T-Y, Yau K-W (1994) Direct modulation by $\mathrm{Ca}^{2+}$-calmodulin of cyclic nucleotide-activated channel of rat olfactory receptor neurons. Nature 368:545-548.

Chik CL, Liu Q-Y, Li B, Karpinski E, Ho AK (1995) cGMP inhibits L-type $\mathrm{Ca}^{2+}$ channel currents through protein phosphorylation in rat pinealocytes. J Neurosci 15:3104-3109.

Davidoff M, Schulze W (1990) Combination of the peroxidase antiperoxidase (PAP)- and the avidin-biotin-peroxidase complex (ABC)techniques: an amplification alternative in immunocytochemical staining. Histochemistry 93:531-536.

Deguchi T (1979) Role of adenosine 3',5'-monophosphate in the regulation of circadian oscillation of serotonin $N$-acetyltransferase activity in cultured chicken pineal gland. J Neurochem 33:45-51.

Dhallan RS, Yau K-W, Schrader KA, Reed RR (1990) Primary structure and functional expression of a cyclic nucleotide-activated channel from olfactory neurons. Nature 347:184-187.

Dhallan RS, Macke JP, Eddy RL, Shows TB, Reed RR, Yau K-W, Nathans J (1992) Human rod photoreceptor cGMP-gated channel: amino acid sequence, gene structure, and functional expression. J Neurosci 12:3248-3256.

Distler M, Biel M, Flockerzi V, Hofmann F (1994) Expression of cyclic nucleotide-gated cation channels in non-sensory tissues and cells. Neuropharmacology 33:1275-1282.

Dryer SE, Henderson D (1991) A cyclic GMP-activated channel in dissociated cells of the chick pineal gland. Nature 353:756-758.

Dryer SE, Henderson D (1993) Cyclic GMP-activated channels of the chick pineal gland: effects of divalent cations, $\mathrm{pH}$, and cyclic AMP. J Comp Physiol [A] 172:271-279.

D'Souza T, Dryer SE (1994) Intracellular free $\mathrm{Ca}^{2+}$ in dissociated cells of the chick pineal gland: regulation by membrane depolarization, second messengers and neuromodulators, and evidence for release of intracellular $\mathrm{Ca}^{2+}$ stores. Brain Res 656:85-94.

Eismann E, Bönigk W, Kaupp UB (1993) Structural features of cyclic nucleotide-gated channels. Cell Physiol Biochem 3:332-351.

Finn JT, Grunwald ME, Yau K-W (1996) Cyclic nucleotide-gated ion channels: an extended family with diverse functions. Annu Rev Physiol 58:395-426.

Frings S, Seifert R, Godde M, Kaupp UB (1995) Profoundly different calcium permeation and blockage determine the specific function of distinct cyclic nucleotide-gated channels. Neuron 15:169-179.

Gordon SE, Downing-Park J, Zimmerman AL (1995) Modulation of the cGMP-gated ion channel in frog rods by calmodulin and an endogenous inhibitory factor. J Physiol (Lond) 486:533-546.

Goulding EH, Ngai J, Kramer RH, Colicos S, Axel R, Siegelbaum SA, Chess A (1992) Molecular cloning and single-channel properties of the cyclic nucleotide-gated channel from catfish olfactory neurons. Neuron 8:45-58.

Goulding EH, Tibbs GR, Siegelbaum SA (1994) Molecular mechanism of cyclic-nucleotide-gated channel activation. Nature 372:369-374.

Haynes LW, Stotz SC (1996) Modulation of cone photoreceptor cGMPgated channels. Biophys J 70:A138.

Hsu Y-T, Molday RS (1993) Modulation of the cGMP-gated channel of rod photoreceptor cells by calmodulin. Nature 361:76-79.

Ikura M, Clore GM, Gronenborn AM, Zhu G, Klee CB, Bax A (1992) Solution structure of a calmodulin-target peptide complex by multidimensional NMR. Science 256:632-638.

Kaku K, Tsuchiya M, Matsuda M, Inoue Y, Kaneko T, Yanaihara N (1985) Light and agonist alter vasoactive intestinal peptide binding and intracellular accumulation of adenosine $3^{\prime}, 5^{\prime}$-monophosphate in the rat pineal. Endocrinology 117:2371-2375. 
Kalsow CM, Wacker WB (1978) Pineal gland involvement in retinainduced experimental allergic uveitis. Invest Ophthalmol Vis Sci 17:774-783.

Kaupp UB, Niidome T, Tanabe T, Terada S, Bönigk W, Stühmer W, Cook NJ, Kangawa K, Matsuo H, Hirose T, Miyata T, Numa S (1989) Primary structure and functional expression from complementary DNA of the rod photoreceptor cyclic GMP-gated channel. Nature 342:762-766.

Kaupp UB (1995) Family of cyclic nucleotide gated ion channels. Curr Opin Neurobiol 5:434-442.

Klein DC (1986) Photoneural regulation of the mammalian pineal gland. Ciba Found Symp 117:38-56.

Korf H-W, White BH, Schaad NC, Klein DC (1992) Recoverin in pineal organs and retinae of various vertebrate species including man. Brain Res 595:57-66.

Korf H-W (1994) The pineal organ as a component of the biological clock. Ann NY Acad Sci 719:13-42.

Korf H-W, Møller M, Gery I, Zigler JS, Klein DC (1985) Immunocytochemical demonstration of retinal S-antigen in the pineal organ of four mammalian species. Cell Tissue Res 239:81-85.

Körschen HG, Illing M, Seifert R, Sesti F, Williams A, Gotzes S, Colville C, Müller F, Dosé A, Godde M, Molday L, Kaupp UB, Molday RS (1995) A $240 \mathrm{kDa}$ protein represents the complete $\beta$-subunit of cyclic nucleotide-gated channel from rod photoreceptors. Neuron 15:627-636.

Kozak M (1984) Compilation and analysis of sequences upstream from the translational start site in eukaryotic mRNAs. Nucleic Acids Res 12:857-872.

Liman ER, Tytgat J, Hess P (1992) Subunit stoichiometry of a mammalian $\mathrm{K}^{+}$channel determined by construction of multimeric cDNAs. Neuron 9:861-871.

Liman ER, Buck LB (1994) A second subunit of the olfactory cyclic nucleotide-gated channel confers high sensitivity to cAMP. Neuron 13:611-621.

Liu M, Chen T-Y, Ahamed B, Li J, Yau K-W (1994) Calcium-calmodulin modulation of the olfactory cyclic nucleotide-gated cation channel. Science 266:1348-1354.

Lolley RN, Craft CM, Lee RH (1992) Photoreceptors of the retina and pinealocytes of the pineal gland share common components of signal transduction. Neurochem Res 17:81-89.

Matthews G, Watanabe S-I (1988) Activation of single ion channels from toad retinal rod inner segments by cyclic GMP: concentration dependence. J Physiol (Lond) 403:389-405.

Max M, McKinnon PJ, Seidenman KJ, Barrett RK, Applebury ML, Takahashi JS, Margolskee RF (1995) Pineal opsin: a nonvisual opsin expressed in chick pineal. Science 267:1502-1506.

Nakatani K, Koutalos Y, Yau K-W (1995) $\mathrm{Ca}^{2+}$ modulation of the cGMP-gated channel of bullfrog retinal rod photoreceptors. J Physiol (Lond) 484:69-76.

O’Neil KT, DeGrado WF (1990) How calmodulin binds its targets: sequence independent recognition of amphiphilic $\alpha$-helices. Trends Biochem Sci 15:59-64.

Okano T, Yoshizawa T, Fukada Y (1994) Pinopsin is a chicken pineal photoreceptive molecule. Nature 372:94-97.

Palczewski K, Carruth ME, Adamus G, McDowell JH, Hargrave PA (1990) Molecular, enzymatic and functional properties of rhodopsin kinase from rat pineal gland. Vision Res 30:1129-1137.

Perry RJ, McNaughton PA (1991) Response properties of cones from the retina of the tiger salamander. J Physiol (Lond) 433:561-587.

Picones A, Korenbrot JI (1995) Permeability and interaction of $\mathrm{Ca}^{2+}$ with cGMP-gated ion channels differ in retinal rod and cone photoreceptors. Biophys J 69:120-127.
Pratt BL, Takahashi JS (1989) Vasoactive intestinal polypeptide and $\alpha_{2}$-adrenoceptor agonists regulate adenosine 3 ',5'-monophosphate accumulation and melatonin release in chick pineal cell cultures. Endocrinology 125:2375-2384.

Reig JA, Yu L, Klein DC (1990) Pineal transduction: adrenergic-cyclicAMP-dependent phosphorylation of cytoplasmic $33 \mathrm{kDa}$ protein (MEKA) which binds beta, gamma-complex of transducin. J Biol Chem 265:5816-5824.

Rieke F, Schwartz EA (1994) A cGMP-gated current can control exocytosis at cone synapses. Neuron 13:863-873.

Sato T, Kaneko M, Fujieda H, Deguchi T, Wake K (1994) Analysis of the heterogeneity within bovine pineal gland by immunohistochemistry and in situ hybridization. Cell Tissue Res 277:201-209.

Sáez JC, Moreno AP, Spray DC (1994) Norepinephrine induces $\mathrm{Ca}^{2+}$ release from intracellular stores in rat pinealocytes. $J$ Pineal Res 16:57-64.

Schaad NC, Vanecek J, Rodriguez IR, Klein DC, Holtzclaw L, Russell JT (1995) Vasoactive intestinal peptide elevates pinealocyte intracellular calcium concentrations by enhancing influx: evidence for involvement of a cyclic GMP-dependent mechanism. Mol Pharmacol 47:923-933.

Schomerus C, Laedtke E, Korf H-W (1995) Calcium responses of isolated, immunocytochemically identified rat pinealocytes to noradrenergic, cholinergic and vasopressinergic stimulations. Neurochem Int 27:163-175.

Somers RL, Klein DC (1984) Rhodopsin kinase activity in the mammalian pineal gland and other tissues. Science 226:182-184.

Sugden LA, Sugden D, Klein DC (1987) $\alpha_{1}$-adrenoceptor activation elevates cytosolic calcium in rat pinealocytes by increasing net influx. J Biol Chem 262:741-745.

Takahashi JS (1995) Molecular neurobiology and genetics of circadian rhythms in mammals. Annu Rev Neurosci 18:531-553.

Takahashi JS, Murakami N, Nikaido SS, Pratt BL, Robertson LM (1989) The avian pineal, a vertebrate model system of the circadian oscillator: cellular regulation of circadian rhythms by light, second messengers, and macromolecular synthesis. Recent Prog Horm Res 45:279-352.

Torre V, Straforini M, Sesti F, Lamb TD (1992) Different channel-gating properties of two classes of cyclic GMP-activated channel in vertebrate photoreceptors. Proc R Soc Lond [Biol] 250:209-215.

Voisin P, Guerlotté J, Collin J-P (1988) An antiserum against chicken hydroxyindole- $O$-methyltransferase reacts with the enzyme from pineal gland and retina and labels pineal modified photoreceptors. Mol Brain Res 4:53-61.

Voisin P, Collin J-P (1986) Regulation of chicken pineal arylalkylamine$N$-acetyltransferase by postsynaptic $\alpha_{2}$-adrenergic receptors. Life Sci 39:2025-2032.

Weyand I, Godde M, Frings S, Weiner J, Müller F, Altenhofen W, Hatt H, Kaupp UB (1994) Cloning and functional expression of a cyclicnucleotide-gated channel from mammalian sperm. Nature 368:859-863.

Yang R-B, Foster DC, Garbers DL, Fülle H-J (1995) Two membrane forms of guanylyl cyclase found in the eye. Proc Natl Acad Sci USA 92:602-606.

Yuwiler A (1983) Vasoactive intestinal peptide stimulation of pineal serotonin- $N$-acetyltransferase activity: general characteristics. J Neurochem 41:146-153.

Záborszky L, Léránth C (1985) Simultaneous ultrastructural demonstration of retrogradely transported horseradish peroxidase and choline acetyltransferase immunoreactivity. Histochemistry 82:529-537. 